Egypt. Acad. J. biolog. Sci., 2(2): 33 - 44(2010)

Email: egyptianacademic@yahoo.com

Received: 20/6/2010
C. Physiology \& Molecular Biology

ISSN: 2090-0767

www.eajbs.eg.net

\title{
Biochemical effects of some insect growth regulators on the house fly, Musca domestica (diptera: muscidae).
}

\author{
Assar, A.A.; Abo El-Mahasen, M.M.; Khalil, M.E.; and Mahmoud, S.H. \\ Zool. Dep., Fac. of Science, Menoufiya Univ., Shebin El-Kom
}

\begin{abstract}
The current work was carried out to evaluate the biochemical effects of five insect growth regulators (IGRs); applaud (buprofezin), consult (hexaflumuron) and match (lufenuron) as chitin synthesis inhibitors (CSIs); mimic (tebufenozide) as ecdysone agonist (EA) and admiral (pyriproxyfen) as juvenile hormone analogue (JHA) against the housefly $M$. domestica. The IGRs were applied by feeding $1^{\text {st }}$ instar larvae on diets mixed with these IGRs at 100 and1000 ppm for three days to determine the effects of these IGRs on the glucose, protein and the amino acid content as well as the phosphatase and transaminase enzymes.

The obtained results indicated that all the tested IGRs except applaud increased the glucose content in the homogenate of $3^{\text {rd }}$ larval instar of M.domestica. The total protein content and total concentration of amino acids increased with applaud, admiral and mimic, while decreased with match and consult. In addition, the tested IGRs significantly increased the activity of acid and alkaline phosphatase .Mimic exhibited a severe reduction in the activity of AcP. Admiral, mimic and applaud induced a significant stimulatory effect on total AST activity, while match induced inhibitory effect at $1000 \mathrm{ppm}$. Consult had no effect on the total activity of AST. With respect to the total ALT activity, applaud and admiral induced a significant stimulatory effect, in contrast, match and consult elicited inhibitory effect on the total ALT activity.
\end{abstract}

Key words: Insect growth regulators (IGRs), Acid phosphatase (AcP), Alkaline phosphatase (AlP), Aspartate aminotransferase (AST), Alanine aminotransferase (ALT).

\section{INTRODUCTION}

The housefly, Musca domestica is found in homes, horse stables, poultry farms, and ranches in enormous numbers. The houseflies are carriers of more than 65 human and animal intestinal diseases, including bacterial infections such as salmonellosis, shigellosis and cholera; protozoan infections such as amoebic dysentery; helminthic infections such as pinworms, roundworms, hookworms and tapeworms as well as viral and rickettsial infections. Flies also transmit eye diseases such as trachoma and epidemic conjunctivitis and infectious wounds or skin diseases such as cutaneous diphtheria, mycoses, yaws and leprosy (Greenberg, 1965). Because of its importance as a public health pest, many insecticides have been used directly or indirectly in the control of $M$. domestica. Throughout the world, houseflies have developed resistance to these insecticides. Furthermore, resistance has been recorded for most conventional insecticides. As a consequence, it provides impetus to study new alternatives and more ecologically acceptable methods of insect control.

The insect growth regulators (IGRs) have been used in a variety of practical applications and were described as agents that elicit their primary action on insect metabolism, ultimately interfering and disrupting the process of growth, development and metamorphosis of the target insects, particularly when applied during the sensitive period of insect development (Ishaaya and Horowitz, 1997).

The biochemical effects of IGRs on the carbohydrate content on $M$. domestica were studied by Ishaaya and Casida (1974) 
using diflubenzuron and El- Kordy (1985) using diflubenzuron and triflumuron.

Effects of IGRs on the protein content on $M$. domestica were studied by Ishaaya and Casida (1974) with diflubenzuron; ElKordy (1985) by diflubenzuron and triflumuron; Bakr (1986) with dimilin, BAY SIR and altosid; Hamdy (1988) with chlorfluazuron and teflubenzuron and ElBermawy (1994) with atabron (IKI 7899), BAY SIR and pyriproxyfen.

Effects of IGRs on the amino acids of $M$. domestica were studied by Youssef (1985) using JH1 and by Bakr (1986) using dimilin, BAY SIR and altosid.

Effect of IGRs on phosphatase and transaminase enzymes on insects was studied by several authors, but little work was done on $M$. domestica, such as ElBermawy (1994) studied the effect of BAY SIR 8514 and pyriproxyfen on phosphatase enzymes and stated that the tested IGRs inhibited the acid phosphatase (AcP) activity in larval, pupal and adult stage.

The present study was carried out to evaluate the impacts of five insect growth regulators (applaud, consult, match, mimic and admiral) on the the glucose, protein and the amino acid content as well as the phosphatase and transaminase enzymes on $M$. domestica larvae.

\section{MATERIALS AND METHODS} 1-Maintenance of culture and rearing technique

The stock colony of $M$.domestica was obtained from the Research Institute of Medical Entomology, Dokki, Giza.The breeding method and maintenance of the colony was undertaken according to (Hashem and Youssef 1991).

2-The tested insect growth regulators:A-Chitin synthesis inhibitors:-

I- Buprofezin (Applaud 25\% WP): 2[(1,1-dimethylethyl)imino] tetrahydro-3(1-methylethyl)-5-phenyl-4H-1, 3, 5thiadiazin-4-one

II-Hexaflumuron(Consult 10\% EC): 1-[3, 5-dichloro-4-(1, 1, 2, 2-tetrafluoroethoxy) phenyl]-3- (2, 6-difluorobenzoyl) urea

III-Lufenuron (Match 10\% EC): N-[[[2, 5-dichloro-4-(1, $1, \quad 2, \quad 3, \quad 3, \quad 3$ hexafluoropropoxy) - = phenyl] amino] carbonyl]-2, 6-difluorobenzamide
B-Ecdysone agonist:-

Tebufenozide(Mimic $24 \%$ EC): 3, 5dimethylbenzoic acid 1-(1, 1dimethylethyl)-= 2-(4-ethylbenzoyl) hydrazide

C- Juvenile hormone analogue: -

Pyriproxyfen(Admiral $10 \%$ EC): 2-[1methyl-2-(4-phenoxyphenoxy) ethoxy] pyridine

\section{3-Biochemical studies}

Preparation of samples for biochemical studies

First instar larvae of $M$.domestica were treated with 100 and $1000 \mathrm{ppm}$ of the tested insect growth regulators to study the effect of these IGRs on total protein, glucose, phosphatase and transaminase enzymes in the whole larval body extracts. Larvae fed on media with water were used as control. Larvae were collected after three days of treatment and homogenized in distilled water .Homogenates were centrifuged at $5000 \mathrm{rpm}$ for $15 \mathrm{~min}$. The supernatant was placed in tubes for analysis.

\section{A. Determination of total glucose content: \\ Total glucose content in larval homogenate was estimated according to (Trinder, 1969).}

\section{B. Determination of total protein content:}

Total protein content in larval homogenate was estimated according to (Henry 1964).

\section{C-Amino acids}

The samples were hydrolyzed according to (Ibrahim and El-Eraqy, 1996) and analyzed by Lc3000 Amino Acid Analyzer.

D- Determination of alkaline phosphatase activity

The activity of alkaline phosphatase in larval homogenate was estimated according to (Belfield and Goldberg 1974).

E- Determination of acid phosphatase activity

The activity of acid phosphatase in larval homogenate was estimated according to (Kind and King 1954). 


\section{F-Determination of aspartate aminotransferase (AST/ GOT)}

The glutamic transaminase enzyme, aspartate aminotransferase catalyses the transfer of the amino group of glutamic acid and pyruvic acid in reversible reactions. The transaminase activity is proportional to the amount of oxalate or pyruvate formed over a definite period of time and measured by a reaction with 2,4 dinitrophenylhdrazine in alkaline solution (Murray, 1984a).

\section{G-Determination of alanine aminotransferase (ALT/ GPT)}

The glutamic transaminase enzyme, alanine aminotransferase catalyses the transfer of the amino group of glutamic acid and pyruvic acid in reversible reactions. The transaminase activity is proportional to the amount of oxalate or pyruvate formed over a definite period of time and measured by a reaction with 2, 4- dinitrophenylhdrazine in alkaline solution (Murray, 1984b).

\section{RESULTS AND DISCUSSION}

\section{1- Effect of the tested IGRs on the} total glucose content:-

Results given in Table (1) indicated that all the tested IGRs except applaud increased the glucose content of $3^{\text {rd }}$ larval instar of M.domestica treated as $1^{\text {st }}$ larval instar.

Table 1: Effect of the tested IGRs on the total glucose content of the $3^{\text {rd }}$ instar larvae of $M$. domestica treated as $1^{\text {st }}$ larval instar.

\begin{tabular}{|c|c|c|c|c|c|c|c|}
\hline \multirow{2}{*}{$\begin{array}{c}\text { IGRs } \\
\begin{array}{c}\text { Conc. } \\
\text { ppm }\end{array}\end{array}$} & Applaud & Consult & Match & Mimic & F- Value & \\
\cline { 2 - 7 } Control & $44.60 \pm 0.40$ & $44.60 \pm 0.40$ & $44.60 \pm 0.40$ & $44.60 \pm 0.40$ & $44.60 \pm 0.40$ & \\
\hline 100 & $43.00 \pm 0.58$ & $179.33 \pm 0.67$ & $80.00 \pm 0.58$ & $70.67 \pm 0.33$ & $48.00 \pm 0.58$ & 10647.63 & $<0.05$ \\
\hline 1000 & $24.67 \pm 0.33$ & $191.00 \pm 0.58$ & $97.00 \pm 0.58$ & $173.33 \pm 0.67$ & $162.00 \pm 0.58$ & 18542.51 & $<\mathbf{0 . 0 5}$ \\
\hline F- Value & 599.47 & 23897.01 & 2977.72 & 22987.31 & 18604.39 & & \\
\hline$\rho$ & $<\mathbf{0 . 0 5}$ & $<\mathbf{0 . 0 5}$ & $<\mathbf{0 . 0 5}$ & $<\mathbf{0 . 0 5}$ & $<\mathbf{0 . 0 5}$ & \\
\hline
\end{tabular}

The increasing or/decreasing effect was dose dependent. Considering the increase in glucose content, consult and mimic were more effective than admiral and match. The glucose content was 179.33 and 191.00 $\mathrm{mg} / \mathrm{gm}$ at 100 and $1000 \mathrm{ppm}$ of consult, respectively. Whereas, the glucose content was $44.60 \mathrm{mg} / \mathrm{gm}$ in control group. Applaud decreased the glucose content which was 43 and $24.67 \mathrm{mg} / \mathrm{gm}$ at 100 and $1000 \mathrm{ppm}$, respectively.

The increase in glucose (or chitin or total carbohydrates) content was noticed by El-Sherif (1995) and El-Sokkary (2003) using pyriproxyfen against Schistocerca gregaria. The reduction in glucose content induced by applaud in the present study is similar to the results reported by Ishaaya and Casida (1974) using diflubenzuron and El-Kordy (1985) using triflumuron and diflubenzuron against $M$. domesiica. Pyriproxyfen induced reduction in glucose content of mosquitoes (Ranjit and Dash, 1994); on Spodoptera littoralis (Abdel-Aal, 2002) and on Agroitis ipsilon (ElSheikh, 2002).

\section{2 -Effect of the tested IGRs on the} total protein content:-

The data obtained (Table 2) shows that applaud significantly increased the total protein content in the homogenate of $3^{\text {rd }}$ instar larvae of $M$. domestica treated as $1^{\text {st }}$ larval instar; whereas admiral and mimic slightly increased the total protein content. The total protein was 3.9 and $8.1 \mathrm{mg} / \mathrm{gm}$ at 100 and $1000 \mathrm{ppm}$ of applaud, respectively, while it was 2.7 $\mathrm{mg} / \mathrm{gm}$ in the control group. On the contrary, match and consult decreased the total protein content. Match was more effective than consult. The total protein content was 2.3 and $0.2 \mathrm{mg} / \mathrm{gm}$ at 100 and $1000 \mathrm{ppm}$ of match, 
respectively. From these results, it can be concluded that the increase in total protein content may be due to the natural increase of protective hydrolytic and detoxifying enzymes that usually take place shortly after treatment.

Similar increase in the protein content of the same insect with dimilin, BAY SIR and altosid was reported by Bakr (1986). The protein content was increased by pyriproxyfen in other insect species by (El-Sokkary, 2003) against $S$. gregaria and by (Farag, 2001) against $S$. littoralis.

On the contrary, the protein content was unaffected by diflubenzuron and triflumuron( El-Kordy, 1985). While, the protein content was decreased by pyriproxyfen (El-Bermawy, 1994) and by methoxyfenozide (Assar and AboShaeshae, 2004).

Table 2: Effect of the tested IGRs on the total protein content of the $3^{\text {rd }}$ instar larvae of $M$. domestica treated as $1^{\text {st }}$ larval instar.

\begin{tabular}{|c|c|c|c|c|c|c|c|}
\hline IGRs & \multicolumn{5}{|c|}{ Mean total protein content $\mathrm{mg} / \mathrm{gm}$ tissue \pm S.E. } & \multirow[t]{3}{*}{ F- Value } & \multirow[t]{3}{*}{$\rho$} \\
\hline & Applaud & Consult & Match & Mimic & Admiral & & \\
\hline Control & $2.7 \pm 0.04$ & $2.7 \pm 0.04$ & $2.7 \pm 0.04$ & $2.7 \pm 0.04$ & $2.7 \pm 0.04$ & & \\
\hline 100 & $3.9 \pm 0.04$ & $2.7 \pm 0.01$ & $2.3 \pm 0.02$ & $2.9 \pm 0.00$ & $2.9 \pm 0.01$ & 5.35 & $<0.05$ \\
\hline 1000 & $8.1 \pm 0.01$ & $2.4 \pm 0.02$ & $0.2 \pm 0.01$ & $3 \pm 0.00$ & $3.4 \pm 0.02$ & 187.62 & $<0.05$ \\
\hline F- Value & 75.74 & 0.058 & 30.53 & 0.40 & 1.74 & & \\
\hline$\rho$ & $<0.05$ & $<0.05$ & $<0.05$ & $<0.05$ & $<0.05$ & & \\
\hline
\end{tabular}

$\rho<0.05=$ significant

The reduction in protein content induced by match and consult in the present study on $M$. domestica larvae was similar to the findings in other insect species by different IGRs, such as, by pyriproxyfen (El-Sherif, 1995) and lufenuron Bakr et al. (2007) against $S$. gregaria; pyriproxyfen (Shaurub et al., 1998), and tebufenozide (Abd El-Mageed, 2008) against $S$. littoralis;; pyriproxyfen against $A$. ipsilon (El- Sheikh, 2002); and by pyriproxyfen and hexaflumuron against Parasarcophaga aegyptiaca (Assar, 2004).

The decline in protein content obtained by match and consult can be explained according to Mitilin et al. (1977) by the inhibition of protein synthesis as a result of inhibition of DNA and RNA synthesis as the first sign of cell death.

El-Bermawy, (1994) verified that treatment of $M$. domestica larvae with variable level of IKI, BAY SIR and sumilarv resulted in a reduction in the total protein content of $3^{\text {rd }}$ instar larvae of $M$. domestica, while an increase in total protein content of $1^{\text {st }}$ and $2^{\text {nd }}$ larvae was recorded. The author attributed this reduction to the inhibitory role of the tested IGRs on tissue protein synthesis, whereas, the high levels of total protein in tissues of $1^{\text {st }}$ and $2^{\text {nd }}$ larval instars may be referred either to a special stimulatory effect of the tested IGRs or unaffected protein synthesis.

Bakr et al., (2007) reported that the reduction of protein level might be due to the destructive effect of match on some of the cerebral neurosecrotory cells of the brain responsible for secretion of the proteins of the treated nymphs of $S$. gregaria.

\section{3 -Effect of the tested IGRs on amino} acids:-

The chemical analysis of larval body of $3^{\text {rd }}$ instar larvae of M.domestica by means of the Amino Acid Analyzer indicated that the body contained 16 different free amino acids (Table 3).

The data in Table (3) shows that the most abundant amino acids in the body of the untreated and treated larvae of M.domestica by the tested IGRs were proline and glutamic acid. This was followed by aspartic, phenylalanine, leucine, lycine, tyrosine, arginine ,alanine, histidine, serine, threonine, valine, and isoleucine. The concentration of glycine and methionine was much lower.

Generally, the total concentration of amino acids was greatly increased in the 
larval body by treatment of applaud, mimic and admiral, while decreased by treatment with consult and match. This effect (increase or/ decrease) was dose dependant. (Table 3).

The data in Table (3) shows that proline was the highest value, its concentration was $299.83,144.11,246.25$, 471.37 and $238.08 \mu \mathrm{g} / \mathrm{ml}$ at $100 \mathrm{ppm}$ of applaud, consult, match, mimic and admiral, respectively. While proline value at $1000 \mathrm{ppm}$ was $423.93,143.94,260.24$, 0.0 and $831.59 \mu \mathrm{g} / \mathrm{ml}$ by the above mentioned tested IGRs, respectively. The proline value with the control was 203. 04 $\mu \mathrm{g} / \mathrm{ml}$.

Data presented in Table (3) shows that methionine and glycine were the lowest concentration from all the amino acids. For example,

methionine value was $46.64,20.10,10.27$, 22.79 and 32.49 at $100 \mathrm{ppm}$ of applaud, consult, match, mimic and admiral, respectively. While methionine value at $1000 \mathrm{ppm}$ was $46.92,8.07,7.29,14.88$ and $29.34 \mu \mathrm{g} / \mathrm{ml}$ by the above mentioned IGRs. The methionine value with the control was $23.09 \mu \mathrm{g} / \mathrm{ml}$.

Table 3: Effect of the tested IGRs on the amino acids of the third instar larvae of $M$. domestica treated as $1^{\text {st }}$ larval instar.

\begin{tabular}{|c|c|c|c|c|c|c|c|c|c|c|c|c|}
\hline \multirow{3}{*}{\multicolumn{2}{|c|}{ IGRs }} & \multirow[b]{3}{*}{0.0} & \multicolumn{2}{|l|}{ Applaud } & \multicolumn{2}{|l|}{ Consult } & \multicolumn{2}{|c|}{ Match } & \multicolumn{2}{|l|}{ Mimic } & \multicolumn{2}{|l|}{ Admiral } \\
\hline & & & \multicolumn{10}{|c|}{ Conc. $(\mu \mathrm{g} / \mathrm{ml})$} \\
\hline & & & 100 & 1000 & 100 & 1000 & 100 & 1000 & 100 & 1000 & 100 & 1000 \\
\hline \multirow[t]{2}{*}{ Acidic } & Aspartic & 79.81 & 123.55 & 143.06 & 83.26 & 63.79 & 53.39 & 52.52 & 86.20 & 134.18 & 94.67 & 105.35 \\
\hline & Glutamic & 155.21 & 243.36 & 302.55 & 167.80 & 116.17 & 95.20 & 94.78 & 157.12 & 362.93 & 172.03 & 196.10 \\
\hline \multirow[t]{3}{*}{ Basic } & Arginine & 66.96 & 114.54 & 164.95 & 66.01 & 44.13 & 30.65 & 26.72 & 58.27 & 309.68 & 82.97 & 86.96 \\
\hline & Histidine & 63.93 & 112.84 & 135.07 & 67.41 & 41.77 & 32.84 & 28.61 & 64.61 & 77.51 & 80.01 & 93.00 \\
\hline & Lycine & 75.25 & 123.54 & 156.96 & 78.54 & 55.01 & 48.15 & 44.89 & 86.12 & 126.11 & 89.88 & 106.64 \\
\hline \multirow[t]{11}{*}{ Neutral } & Alanine & 65.82 & 95.96 & 127.72 & 66.97 & 49.56 & 47.55 & 41.53 & 66.42 & 77.09 & 71.60 & 84.67 \\
\hline & Glycine & 21.35 & 32.76 & 44.54 & 23.71 & 17.24 & 15.25 & 12.53 & 22.37 & 39.78 & 25.20 & 27.46 \\
\hline & Isoleucine & 30.56 & 48.82 & 63.91 & 32.67 & 23.40 & 17.40 & 15.04 & 26.79 & 27.47 & 35.04 & 38.60 \\
\hline & Leucine & 77.09 & 119.37 & 126.35 & 79.01 & 58.33 & 42.31 & 37.85 & 66.58 & 73.42 & 89.72 & 96.14 \\
\hline & Methionine & 23.09 & 46.64 & 46.92 & 20.10 & 8.07 & 10.27 & 7.29 & 22.79 & 14.88 & 32.49 & 29.34 \\
\hline & Phenyl alanine & 78.07 & 146.97 & 188.43 & 92.15 & 54.21 & 43.36 & 37.02 & 87.75 & 78.87 & 117.48 & 126.11 \\
\hline & Proline & 203.04 & 299.83 & 423.93 & 144.11 & 143.94 & 246.25 & 260.24 & 471.37 & - & 238.08 & 831.59 \\
\hline & Serine & 37.03 & 56.75 & 70.33 & 39.07 & 26.72 & 22.44 & 21.76 & 35.65 & 81.08 & 39.65 & 44.99 \\
\hline & Threonine & 34.94 & 54.74 & 68.27 & 38.09 & 24.62 & 20.56 & 19.78 & 33.22 & 74.30 & 38.41 & 43.63 \\
\hline & Tyrosine & 69.17 & 124.00 & 142.10 & 74.29 & 43.00 & 36.42 & 26.51 & 68.86 & 59.69 & 100.19 & 102.64 \\
\hline & $\begin{array}{l}\text { Valine } \\
\end{array}$ & 30.69 & 55.11 & 72.55 & 31.40 & 22.15 & 23.39 & 18.54 & 33.84 & 34.18 & 37.70 & 48.02 \\
\hline \multicolumn{2}{|l|}{ Total } & 1112.01 & 1798.78 & 2277.64 & 1104.59 & 792.11 & 785.43 & 745.61 & 1387.96 & 1571.17 & 1345.12 & 2061.24 \\
\hline
\end{tabular}

The values of some amino acids were not affected by increasing the tested IGRs, for example, methionine value by applaud was 46.64 and 46.92; aspartic value was 53.39 and 52.52 by match; serine value was $22.44,21.76$ by match; threonine value was 20.56 and 19.78 by match; isoleucine value was 26.79 and 27.47 by mimic, valine value was 33.84 and $34.18 \mu \mathrm{g} / \mathrm{ml}$ by mimic at 100 and $1000 \mathrm{ppm}$, respectively. Also, proline disappears completely at $1000 \mathrm{ppm}$ of mimic.

Match was more effective than consult at the two tested concentrations. These two compounds decreased all 16 amino acids and the total concentration of amino acids. Although, at $100 \mathrm{ppm}$ of consult, while the values of most amino acids slightly increased, the value of arginine and proline decreased. Also, the total concentration of amino acids was 1104.59 at $100 \mathrm{ppm}$ of consult, while was $1112.01 \mu \mathrm{g} / \mathrm{ml}$ in the control.
It is clear from the data in Table (3) the tested IGRs ( applaud, mimic and admiral) increased the values of free amino acids and the total concentration of amino acids in the larval body of M.domestica .This effect was dose dependant . The total amino acids at 100 ppm was $1798.78,1387.96$ and 1345.12 $\mu \mathrm{g} / \mathrm{ml}$ by applaud, mimic and admiral, respectively, while at $1000 \mathrm{ppm}$ of the same IGRs was 2227.64, 1571.17 and $2061.24 \mu \mathrm{g} / \mathrm{ml}$, respectively.

This result agrees with those obtained by Bakr (1986) on the same insect after feeding the 2 days old larvae with $1 \mathrm{ppm}$ of dimilin, BAY SIR 8514 and altosid. These IGRs increased the values of the majority of the free amino acids.

On the other hand, the tested IGRs (CSIs) consult and match decreased the values of free amino acids and the total concentration of amino acids. Also, Bakr (1986) stated that dimilin, BAY SIR 8514 and altosid decreased some amino acids. 
Valine decreased by dimilin and altosid, it increased by BAY SIR 8514. Some amino acids did not show up in the control but appear after treatment with certain IGRs. On the contrary, ethanolamine appears in the control and disappears after treatment with BAY SIR 8514 and altosid.

Data in Table (3) shows that the most abundant amino acids in the body of the untreated and treated larvae of M.domestica were proline and glutamic acids. While, Bakr (1986) stated that, valine, and glutamic acid were the most abundant in the larval body of M.domestica.

No general pattern can be recognized in the variation of individual amino acids, many of them decline steadily as development proceeds, while others exhibit a temporary increase. Some of the minor changes reflect merely nutritional variations. Tyrosine and proline are however two exceptions. They show a continous increase when the values are expressed per unit body weight or unit volume of haemolymph. This is especially true during the time approaching puparium formation. It is known that the larval cuticle increases in thickness shortly before pupation (Dennell, 1946).

According to Hackman (1953), the cuticular proteins have a high content of proline and tyrosine. Tyrosine serves as the precursor for the formation of polyphenols and quinones necessary for the formation of the darkening and hardening of the larval cuticle which gives rise to the pupation. The accumulation of these two amino acids suggests therefore the preparation of the larva for the synthesis of cuticular proteins and the associated tanning.

Several experiments indicated that the free amino acids play an important role in detoxication. In Bombyx, glycine is found to conjugate with benzoic acid to form hippuric acid, a detoxication mechanism similar to that in higher animals. The site of hippuricase which regenerates glycine from hippurate has been detected in both fat body and slik gland. Also, histidine like glycine serves as a detoxicating agent in insects (Shyamala, 1964).
Proline is known to be a possible energy reserve since it is a derivative of glutamic acid and could enter the citric cycle after deamination to $\alpha$-ketoglutaric acid (Bursell, 1963). The varying concentration of proline at the different dose levels is probably due to the varying rates of utilizing the amino acids as a source of energy in repair mechanism.

Chen (1974) reported that alanine is a very active transaminase and plays an important role in glucose production from pyruvic acid through transamination. The glutamic alanine transaminase system serves as the main pathway in both the deamination of glutamic acid to ketoglutaric acid and the conversion of pyruvic acid to alanine.

Bakr (1986) mentioned that the increase of free amino acids in the treated stages of M.domestica with dimilin, BAY SIR 8514 and altosid might be interpreted as being due to the destruction of protein. It could be suggested that the variation in quality and quantity of the free amino acids may cause a consequent formation of variable protein structure and /or destruction, hence disturbances in the enzymatic system and /or the building up of some tissues. Also, it may interfere in the transcript of DNA during the process of protein synthesis which may be the reason of the abnormalities.

\section{4- Effect of the tested IGRs on phosphatase enzymes:-}

Results presented in Table 4 showed the activity of acid phosphatase (AcP) of $3^{\text {rd }}$ instar larvae of M.domistica treated as $1^{\text {st }}$ instar larvae with 100 and $1000 \mathrm{ppm}$ of the tested IGRs. The tested IGRs significantly increased the activity of acid phosphatase expect mimic which exhibited a severe (significant) reduction in the enzyme activity as compared to the control. Consult gave the highest increase in acid phosphatase activity followed by match, applaud and admiral. The activity of acid phosphatase was 16.17 and 63.53 IU/1 due to treatment with 100 and 1000 ppm of consult, respectively as compared to $15.43 \mathrm{IU} / 1$ in the control group, while mimic gave 3.23 and $0.54 \mathrm{IU} / 1$ at the same previous concentrations. The tested IGRs induced a significant increase in the activity of alkaline phosphatase as 
compared to the control (Table 4). Admiral gave the highest increase in alkakine phosphatase activity followed by consult, match, mimic and applaud.
Admiral gave 32.50 and $66.20 \mathrm{IU} / 1$ as compared to $14.53 \mathrm{IU} / 1$ in the control group.

Table 4: Effect of the tested IGRs on the activity of phosphatases (Acp. and Alp.) of the $3^{\text {rd }}$ instar larvae of $M$. domestica treated as $1^{\text {st }}$ larval instar.

\begin{tabular}{|c|c|c|c|c|c|c|}
\hline \multirow[t]{2}{*}{ IGRs } & \multirow[t]{2}{*}{ Enzymes (IU/L) } & \multicolumn{3}{|c|}{ Mean enzyme activity $(\mathrm{IU} / \mathrm{L}) \pm$ S.E. } & \multirow[t]{2}{*}{ F- Value } & \multirow[t]{2}{*}{$\rho$} \\
\hline & & 0.0 (Control) & $100 \mathrm{ppm}$ & $1000 \mathrm{ppm}$ & & \\
\hline \multirow[t]{2}{*}{ Applaud } & Acp & $15.43 \pm 0.67$ & $17.6 \pm 0.00$ & $25.27 \pm 0.18$ & 72.22 & $<0.05$ \\
\hline & Alp & $14.53 \pm 0.44$ & $17.93 \pm 0.82$ & $25.70 \pm 0.12$ & 37.82 & $<0.05$ \\
\hline \multirow[t]{2}{*}{ Consult } & Acp & $15.43 \pm 0.67$ & $16.17 \pm 0.23$ & $63.53 \pm 0.03$ & 25320.83 & $<0.05$ \\
\hline & $\overline{\text { Alp }}$ & $14.53 \pm 0.44$ & $18.77 \pm 0.70$ & $58.67 \pm 0.80$ & 337.56 & $<0.05$ \\
\hline \multirow[t]{2}{*}{ Match } & Acp & $15.43 \pm 0.67$ & $27.73 \pm 0.17$ & $32.70 \pm 0.92$ & 258.91 & $<0.05$ \\
\hline & Alp & $14.53 \pm 0.44$ & $18.50 \pm 0.43$ & $41.33 \pm 0.22$ & 55.16 & $<0.05$ \\
\hline \multirow[t]{2}{*}{ Mimic } & Acp & $15.43 \pm 0.67$ & $3.23 \pm 0.12$ & $0.54 \pm 0.04$ & 3755.35 & $<0.05$ \\
\hline & Alp & $14.53 \pm 0.44$ & $15.90 \pm 0.49$ & $36.13 \pm 0.38$ & 205.20 & $<0.05$ \\
\hline \multirow[t]{2}{*}{ Admiral } & Acp & $15.43 \pm 0.67$ & $15.90 \pm 0.23$ & $22.27 \pm 0.67$ & 81.64 & $<0.05$ \\
\hline & $\overline{\text { Alp }}$ & $14.53 \pm 0.44$ & $32.50 \pm 0.61$ & $66.20 \pm 0.50$ & 191.68 & $<0.05$ \\
\hline F- Value & \multirow{2}{*}{\multicolumn{2}{|c|}{ Acp }} & 1975.08 & 1106.96 & & \\
\hline$\rho$ & & & $<0.05$ & $<0.05$ & & \\
\hline F- Value & \multirow{2}{*}{\multicolumn{2}{|c|}{ Alp }} & 23.22 & 112.92 & & \\
\hline$\rho$ & & & $<0.05$ & $<0.05$ & & \\
\hline
\end{tabular}

IU/L: International unit (the amount of enzyme which under defined assay conditions will catalyze the conversion of one micromole of substrate per minute).

Acp: Acid Phosphatase

Alp: Alkaline phosphatase

$\rho<0.05=$ significant

Similar increase in Acp activity was reported by different IGRs, such as, JHA and ecdysterone on Chrysocoris stollii (Saha et al., 1986); 20-HE on Manduca sexta (Caglayan, 1990) ; pyriproxyfen on Culex pipiens (El-Bassal, 1993); pyriproxyfen on Pectinophora gossypiella and Earias insulana (Anan et al., 1993); pyriproxyfen on S. littoralis (Abdel- Aal, 2002) and pyriproxyfen on $A$. ipsilon (El- Sheikh, 2002).

Acid and alkaline phosphatases have been shown to be associated with insect development, especially in relation to nutrition and egg maturation (Tsumuki and Kanehisa, 1984). Acid phosphatase has received considerable attention in developmental studies because of its association with histolysis. It is known that acid phosphatase hydrolyzes a variety of orthophosphorylation reactions (Hollander, 1971). Ecdysone is responsible for increase in the number of lysosomes (Radford and Misch, 1971) and of the activity of acid phosphatase (Van PeltVerkuil, 1979). This indicates that the increased activity of acid phosphatase in the present study may be due to increased number of lysosomes.

In the present study, mimic decreased the activity of Acp in $M$. domestica larvae. Similarly, other IGRs induced decrease in the activity of Acp in other insect species, [20-HE (Prasada, 1990), pyriproxyfen (Mostafa, 1993) and hexaflumuron (Sokar, 1995) ] against $S$. littoralis and BAY SIR on M. domestica (EL-Bermawy, 1994).

In this study, all the tested IGRs increased the activity of Alp in $M$. domestica larvae. These results agree with those obtained by Saha et al. (1986) using JHA and ecdysterone against $C$. stollii; Anan et al. (1993) using pyriproxyfen against $P$. gossypiella and E. insulana ; [Mostafa (1993) using pyriproxyfen, Sokar (1995) using hexaflumuron and AbdelAal (2002) using pyriproxyfen] against $S$. littoralis.

On the other hand, some IGRs reduced the activity of Alp, pyriproxyfen against A. ipsilon (El- Sheikh, 2002), 
while Alp activity was not affected by pyriproxyfen against C. pipiens (El-Bassal, 1993).

Sridhara and Bhat (1963) stated that the increase or decrease of both phosphatases enzymes during development is reflected an increase or decrease in the acid-soluble phosphorus content.

\section{5-Effect of the tested IGRs on transaminase enzymes:-}

Results given in Table (5) clarified the effect of the tested IGRs on the activity of aspartate aminotransferase (AST) and alanine aminotransferase (ALT) of $3^{\text {rd }}$ instar larvae of M.demestica. The obtained results revealed that admiral, mimic and applaud induced a significant stimulatory effect on total AST activity. The total activity was 141 and $176 \mathrm{IU} / 1$ at 100 and $1000 \mathrm{ppm}$ of admiral, respectively, while the total AST activity was $128 \mathrm{IU} / 1$ in the control group. On the contrary, match induced inhibitory effect at $1000 \mathrm{ppm}$ and the total activity was $109 \mathrm{IU} / 1$. Consult had no effect on the total activity of AST.

Table 5: Effect of the tested IGRs on the activity of transaminases (AST. and ALT.) of the $3^{\text {rd }}$ instar larvae of $M$. domestica treated as $1^{\text {st }}$ larval instar.

\begin{tabular}{|c|c|c|c|c|c|c|}
\hline \multirow[t]{2}{*}{ IGRs } & \multirow[t]{2}{*}{ Enzymes (IU/L) } & \multicolumn{3}{|c|}{ Mean enzyme activity (IU/L) \pm S.E. } & \multirow[t]{2}{*}{ F- Value } & \multirow[t]{2}{*}{$\rho$} \\
\hline & & 0.0 (Control) & $100 \mathrm{ppm}$ & $1000 \mathrm{ppm}$ & & \\
\hline \multirow[t]{2}{*}{ Applaud } & AST & $128 \pm 0.10$ & $135 \pm 0.55$ & $156 \pm 0.65$ & 65.90 & $<0.05$ \\
\hline & $\overline{\mathrm{ALT}}$ & $9 \pm 0.58$ & $10 \pm 0.58$ & $12 \pm 0.05$ & 3.50 & $>0.05$ \\
\hline \multirow[t]{2}{*}{ Consult } & AST & $128 \pm 0.10$ & $128 \pm 0.32$ & $127.33 \pm$ & 76.89 & $>0.05$ \\
\hline & ALT & $9 \pm 0.58$ & $7.50 \pm 0.12$ & $5 \pm 0.58$ & 7.35 & $<0.05$ \\
\hline \multirow[t]{2}{*}{ Match } & AST & $128 \pm 0.10$ & $128 \pm 0.18$ & $109 \pm 0.66$ & 25.79 & $<0.05$ \\
\hline & ALT & $9 \pm 0.58$ & $5 \pm 0.01$ & $4.50 \pm 0.50$ & 9.52 & $<0.05$ \\
\hline \multirow[t]{2}{*}{ Mimic } & AST & $128 \pm 0.10$ & $155 \pm 0.30$ & $168 \pm 0.48$ & 63.51 & $<0.05$ \\
\hline & ALT & $9 \pm 0.58$ & $9 \pm 0.03$ & $6.50 \pm 0.76$ & 2.78 & $>0.05$ \\
\hline \multirow[t]{2}{*}{ Admiral } & AST & $128 \pm 0.10$ & $141 \pm 0.09$ & $176 \pm 0.20$ & 46.61 & $<0.05$ \\
\hline & ALT & $9 \pm 0.58$ & $11 \pm 0.29$ & $11.50 \pm 0.09$ & 3.00 & $>0.05$ \\
\hline F-Value & \multirow{2}{*}{\multicolumn{2}{|c|}{ AST }} & 18.79 & 141.16 & & \\
\hline$\rho$ & & & $<0.05$ & $<0.05$ & & \\
\hline F- Value & \multirow[t]{2}{*}{$\mathrm{ALT}$} & & 0.37 & 15.18 & & \\
\hline$\rho$ & & & $>0.05$ & $<0.05$ & & \\
\hline
\end{tabular}

IU/L: International unit (the amount of enzyme which under defined assay conditions will catalyze the conversion of one micromole of substrate per minute).

AST: aspartate aminotransferase

ALT : alanine aminotransferase

$\rho>0.05=$ non-significant, $\rho<0.05=$ significant .

With respect to the effect of the tested IGRs on the total ALT activity of $M$. domestica larvae, it can be concluded that applaud and admiral induced a significant stimulatory effect. The total ALT activity was 10 and $12 \mathrm{IU} / 1$ at 100 and $1000 \mathrm{ppm}$ of applaud, respectively, while it was 9 IU/1 in the control group. In contrast, match and consult elicited inhibitory effect on the total ALT activity which was 5 and $4.5 \mathrm{IU} / 1$ at 100 and $1000 \mathrm{ppm}$ of match, respectively. Mimic elicited inhibitory effect on the total ALT activity at 1000 ppm only. The obtained data also revealed that AST was more active than ALT in both treated and non treated insects.
The inhibitory effect of some tested IGRs on the activity of AST and ALT of M. domestica larvae was in accordance with those obtained by ElSheikh (2002) using pyriproxyfen against A. ipsilon, while the reduction in the activity of AST was reported by Saha et al. (1986) using JHA and ecdysterone against C. stollii and Abdo (2004) against pharaoh ant workers using pyriproxyfen.

The stimulatory effect induced on the total AST activity by admiral, mimic and applaud in the present study agree with the results obtained by pyriproxyfen against S. littoralis (Mostafa, 1993) and (Abdel-Aal, 2002); pyriproxyfen against P. gossypiella and E. insulana (Anan et al. 
,1993).Similarly, applaud and admiral elicited a stimulatory effect on ALT activity against $M$. domestica larvae. These results agree with Saha et al. (1986) using JHA and ecdysterone against $C$. stollii; Anan et al. (1993) using pyriproxyfen against $P$. gossypiella and $E$. insulana and Abdo (2004) using pyriproxyfen against pharaoh ant workers.

Specific types of proteins are synthesized in the haemolymph from precursors of amino acids by enzymatic transamination reactions. Glutamic acid is formed by amino transfer from aspartic acid by aspartate aminotransferase (AST) or from alanine by alanine aminotransferase (ALT). It is probably a very significant enzymatic activity in the final stage of development (Gowda and Ramaiah, 1976).

Transaminase enzymes were considered as key enzymes in the formation of non-essential amino acids, which if formed inside the body not taken from out side in metabolism of nitrogen waste and gluconeogenesis (Mordue and Goldworthy, 1973). The same authors stated that the change in transaminase levels have been correlated with anabolism or catabolism of protein. Maintenance of the balanced "amino acid pool" in insects is the result of various biochemical reactions carried out by a group of enzymes called amino-transferases (Meister, 1957). Also, Gilbert (1967) reported that the level of ALT varies with they amount of synthesized protein. The amino-transaminases alanine is one of the components of oxidative metabolism of proline which is utilized during the initial periods of flights; it acts as a catalytic agent in the carbohydrate metabolism.

\section{REFERENCES}

Abdel-Aal, A. E. (2002): Effect of some insect growth regulators on certain biological, biochemical and histopathological aspects of the cotton leafworm, Spodoptera littoralis (Bosid.) (Lepidoptera: Noctuidae) Ph.D. Thesis, Fac. of Sci., Cairo Univ.

Abd El-Mageed, E. N. (2008): Physiological effects of certain bioagents and an insect growth regulators on the cotton leafworm

Spodoptera littoralis (Bosid.)

(Noctuidae: Lepidoptera). M.Sc.

Thesis, Fac. of Agric., Ain Shams Univ.

Abdo, M. A. (2004): Biological, biochemical and molecular studies on the effect of some insect growth regulators (IGRs) against pharaoh ants (Hymenoptera: Formicidae) M.Sc. Thesis, Fac. of Sci., Ain Shams Univ.

Anan, A. R.; Mona, I. M. and Nagwa, M. H. (1993): Biochemical effect of pyriproxyfen juvenoid on fat and haemolymph proteins of pink bollworm, Pectinophora gossypiella (Saund.) and spiny bollworm, Earias insulana (Boisd.). Ann. Agric. Sci., Ain Shams Univ., Egypt, 38: 761-72.

Assar, A. A. (2004): Histochemical effects of some insect growth regulators on the larvae of flesh fly, Parasarcophaga aegyptiaca Salem (Diptera: Sarcophagidae). J. Egypt. Acad. Soc. Environ. Develop., 5(2):73-89.

Assar, A. A. and Abo-Shaeshae, A. A. (2004): Effect of two insect growth regulators, methoxyfenozide and pyriproxyfen on the housefly, Musca domestica vicina (Diptera: Muscidae). J. Egypt. Ger. Soc. Zool., 44(E): 19-42.

Bakr, R. F. (1986): Morphogenic and physiological aberration induced by certain IGRs in the house fly, Musca domestica. Ph. D. Thesis, Fac. Sci., Ain shams Univ.

Bakr, R. F.; Abdel Fattah, H.M. and Mohamed, E.K. (2007): Effect of chitin synthesis inhibitor, lufenuron on the development, haemolymph and antennal sensilla of Schistocerca gregaria (Forskal) (Orthoptera: Acrididae). African J. Biol. Sci., 3 (2): 35-43.

Belfield, A. and Goldberg, D. M. (1974): Alkaline phosphatase determination, colorimetric method. Enzymes , 12:561.

Bursell, E. (1963): Aspects of the metabolism of amino acids in the tsetse fly, Glossina (Diptera). J. 
Insect Physiol., 9:439-52.

Caglayan, S.H. (1990): Effect of 20hydroxyecdysone on acid phosphatase activity in the larval fat body of Manduca sexta. Biochem. Inter., 20 (3): 511- 18.

Chen, P. S. (1974): Amino acid and protein metabolism in insect development. Adv. Insect Physiol., Vol. (3) pp: 69-89 J.W.L. Beament; J. E. Treheme and V.B., Wigglesworth (Eds.).

Dennell, R. (1946): A study of an insect cuticle; the larval cuticle of Sarcophaga falcitlata Pand. (Diptera). Proc. Roy. Soc., B (133) : 348-73.

El-Bassal, M. M. (1993): Combined effects of insect growth regulators and gamma radiation on Culex pipiens. M. Sc. Thesis, Fac. Sci., Cairo Univ.

El-Bermawy, S. M. (1994): Biochemical aberration induced by certain Insect growth regulators (IGRs) in house fly, Musca domestica (Muscidae: Diptera). Ph.D. Thesis, Fac. Sci. Ain Shams Univ.

El- Kordy, M. W. (1985): The effect of some growth regulators on Musca domestica (L.) Ph. D. Thesis, Fac. Agric., Al- Azhar Univ.

El-Sheikh, T. A. (2002): Effects of application of selected insect growth regulators and plant extracts on some physiological aspects of the black cutworm, Agrotis ipsilon (Huf). Ph. D. thesis, Fac. Sci., Ain Shams Univ.

El-Sherif, L. S. (1995): Effect of juvenile hormone analogue, pyriproxyfen on the main metabolites in the haemolymph of last instar nymph of Schistocerca gregaria (Orthoptera: Acrididae). J. Egypt. Ger. Soc. Zool., 16(E): 125-39.

El-Sokkary, Z. F. (2003): Biological and physiological effects of some insect growth regulators and botanicals on the desert locust Schistocerca gregaria Forskal. M.Sc. Thesis, Fac. Sci., Ain Shams Univ.

Farag, A. M. (2001): Biochemical studies on the effect of some insect growth regulators on the cotton leafworm.
M.Sc. Thesis, Fac. of Agric., Cairo Univ.

Gilbert, L. I. (1967): Lipid metabolism and function of insects. Adv. Insect Physiol., 4: 69-211.

Gowda, V. T. and Ramaiah, T. R. (1976): Effect of induced polyhdrosis on haemolymph transaminases in the larvae of the silkworm Bombyx mori. J. of Invert. Pathol., 28 (2): 271-72.

Greenberg, B. (1965): Flies and disease. Scientific American, 213 (1): 92 99.

Hackman, R. H. (1953): Chemistry of insect cuticle. III. Hardening and darkening of the cuticle. Biochem., 54: 371-77.

Hamdy, A. M. (1988): Biochemical and histological studies of some antimoulting and antihormone compounds on insects. M. Sc. Thesis, Fac. of Agric., Al-Azhar Univ.

Hashem, H. O. and Youssef, N. S. (1991): Developmental changes induced by methanolic extracts of leaves and fruits of Melia azadrach L. on the house fly Musca domestica vicina. J. Egypt. Ger. Soc. Zool., 3: 33552.

Henry, R. J. (1964): Total protein determination, colorometric method.Clinical Chemistry Harper and Row Publishers, New York, p. 181.

Hollander, V. P. (1971): Acid phosphatase. In: The enzymes (Boyer, P., Ed.), 4, $3^{\text {rd }}$ ed., Academic Press. New York.

Ibrahim, N. and El-Eraqy, W. (1996): Protein content and amino acid composition of Nelumbo nucifera seeds and its evalution as hypoglycaemic agent. Egypt. J. Pharm. Sci., 37 (1-6); 635- 41.

Ishaaya, I. and Casida, I. E. (1974): Dietary TH6040 alters composition and enzyme activity of house fly larval cuticle. Pestic. Biochem. and Physiol., 4: 484-90.

Ishaaya, I. and Horowitz, A. R. (1997):Insecticides with novel mode of actions: Overview. pp. 139. In: "Insecticides with novel 
mode of actions, Mechanisms and application" Eds. By Ishaaya, I. and Degheele, D. , Berlin.

Kind, P. R. and King, E. J. (1954): Acid phosphatase determination, colorometric method. J. Clin. Path., $7: 322$.

Meister, A. (1957): Transamination. advanced Enzymol, 19: 185-246.

Mitlin, N.; Wiygul, G. and Haynes, J. W. (1977): Inhibition of DNA synthesis in boll weevil (Anthonomus grandis Boheman) sterilized by dimilin. Pestic., Biochem. Physiol., 7: 55963.

Mordue, W. and Goldsworthy, G. J. (1973): Transaminase levels and uric acid production in adult locusts. Insect Biochem., 3: 419-27.

Mostafa, S. A. (1993): Biochemical effects of some chemical compounds on Spodoptera littoralis (Boised.). Ph. D. Thesis, Fac. Agric., Al-Azhar Univ., Egypt.

Murray, R. (1984a): Aspartate aminotransferase. Clin. Chem.Mosby Co. St. Louis. Toronto. Princeton. 1112-16.

Murray, R. (1984b): Alanine aminotransferase. Clin. Chem.Mosby Co. St. Louis. Toronto. Princeton. 1088-90.

Prasada, C. G. (1990): Effect of 20 hydroxecdysone on the lysosomal enzyme, acid phosphatase activity during the post - embryonic development of Spodoptera litura. Biochem . Inter., 10 (3). 529- 37.

Radford, S. and Misch, D. (1971): Cytological effects of ecdysterone on the midgut cells of the flesh fly, Sarcophaga bullata. J. Cell Biol., 49: 702-11.

Ranjit, M. R and Dash, A. P. (1994): Aphid extracts and juvenoids influence glycogen metabolism in mosquitoes. Tropical Biomedicine, 11: 101-5.

Saha, L. M.; Mandal, S. and Choudhuri, D. K. (1986): The effect of juvenile hormone analogue and ecdysterone on the fat body of female Chrysocoris stolli Wolf (Pentatomidae: Heteroptera: Hemiptera). Zoologische
Jahrbucher, Abteilung fur Allgemeine Zoologie und Physiologic der Tiere., 90: (1) 85100

Shaurub, E. H.; Ahmed, Z. A. and ElNagar, S. E. (1998): Impacts of pyriproxyfen and extracts of Schinus terebtnthifolni. Raddi on development, reproduction and reproductive organs on Spodoptera littoralis (Boisd.) (Lepidoptera Noctuidae). J. Egypt. Ger. Soc. Zool., 27 (E): 57-82.

Shyamala, M. B. (1964): Detoxication of benzoate by glycine conjugation in the silkworm, Bombyx mori L. J. Insect Physiol., 10, 385-91.

Sokar, L. A. (1995): Possible alternatives to classical insecticides in management program of Spodoptera littoralis (Boisd). Ph. D. Thesis, Zagazig Univ., Egypt.

SPSS (2001): SPSS for Windows. Release8. Copyright (C) SPSS Inc.

Sridhara, S. and Bhat, J. V. (1963): Alkaline and acid phosphatases of the silkworm, Bombyx mori (L.) J. Insect Physiol., 9; 693 -701.

Trinder, P. A. (1969):Glucose, enzymatic colorimetric method. Ann. Clin. Biochem., 6:24.

Tsumuki, H. and Kanehisa, K, (1984): Phosphatases in the rice stem borer, Chilo suppersdlis Walker (Lepidoptera, Pyralidae): Some properties and changes of the activities during hibernation. Cytobiology, 21: 177-82.

Van Pelt-Verkuil, E. (1979): Hormone mediated induction of acid phosphatase activity of the fat body of Calliphora erythrocephala prior to metamorphosis. J. Insect Physiol., 55: 965-73.

Youssef, N. S. (1985): Effect of JH on the reproductive system of Musca domestica vicina Macq. Ph.D. Thesis, Fac. Sci., Alexandria Univ. 


\section{ARABIC SUMMARY}

\section{التأثيرات البيوكيميائية لبعض منظمات النمو الحشرية على الذبابة المنزلية

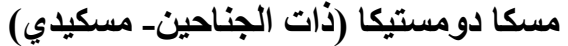

\section{عبادة أبو ذكري عصر- ماجدة محمد أبو المحاسن- محمد السيد خليل- شيماء حسين محمود قسم علم الحيوان- كلية العلوم بشبين الكوم- جامعة المنوفية}

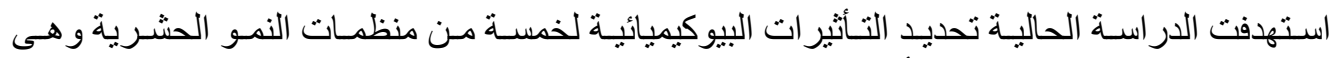

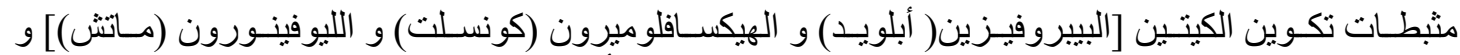

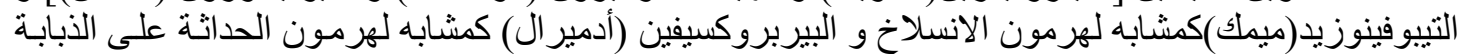

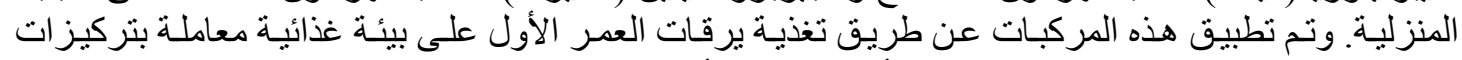

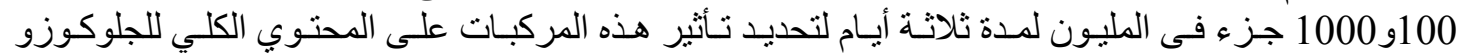

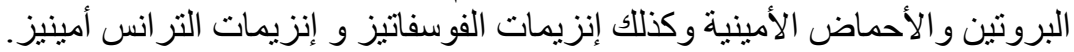

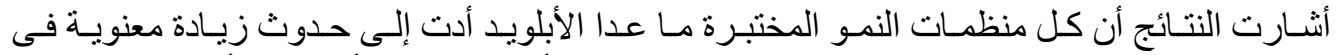

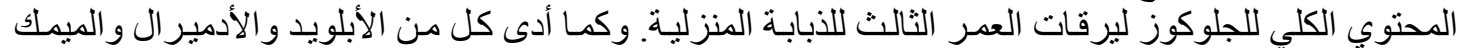

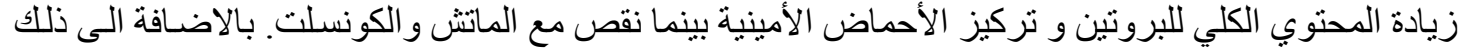

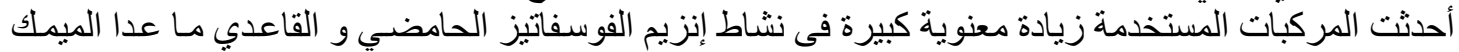

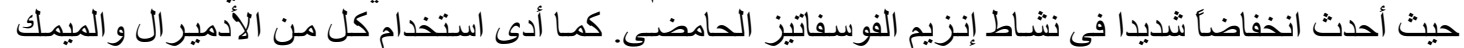

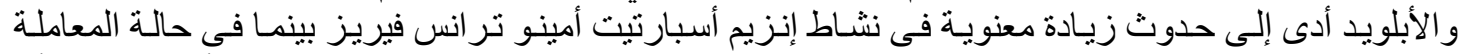

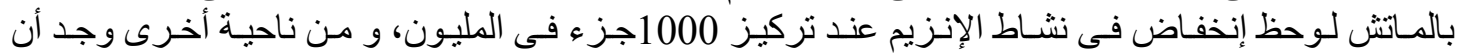

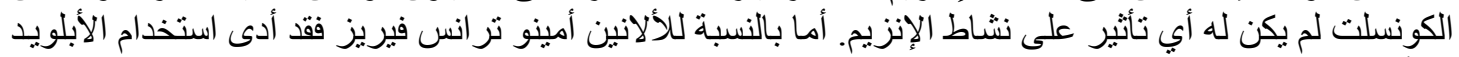

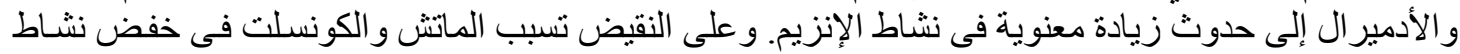

